\title{
A prospective study of acute idiopathic neuropathy. III. Immunological studies
}

\author{
J B WINER,* I A GRAY,* N A GREGSON, $\dagger$ R A C HUGHES, * S LEIBOWITZ, \\ P SHEPHERD,§ W A TAYLOR, * V YEWDALL\|
}

From the Departments of Neurology,* Anatomy, $\dagger$ Pathology, $\ddagger$ Immunology, $\S$ Medicine, $\|$ United Medical and Dental Schools of Guy's and St Thomas's Hospitals, Guy's Hospital, London, UK

SUMMARY The immune responses of 100 patients who presented with an acute idiopathic neuropathy were compared with those of age and sex matched controls. Blood lymphocytes and their subsets were counted with a fluorescent activated cell sorter. CD8 + (putative suppressor) lymphocytes were significantly reduced in the first week of the disease but total lymphocytes, total $\mathrm{T}$ and CD4+ (putative helper) cells were not altered. This reduction depended on the nature of the preceding infection. Serum complement $\mathrm{C} 3$ and $\mathrm{C} 4$ concentrations remained normal and immune complexes were rarely detected with a $\mathrm{Clq}$ binding assay. Complement-fixing antibodies to human peripheral nerve antigens were discovered in the serum of $7 \%$ of patients but only $1 \%$ of controls. Complement-fixing antibodies to galactocerebroside were not discovered in any sera. Enzymelinked immunoassays detected increased antibody responses to galactocerebroside but none at all to human P2 myelin protein in the patient sera. Forty $\mu$ l of serum from five patients injected into the sciatic nerves of rats did not induce significantly more demyelination than the serum from control patients. It is concluded that auto-immune responses can only be detected by these techniques in a small minority of patients with acute idiopathic neuropathy.

The close histological resemblance between experimental allergic neuritis (EAN) and the Guillain-Barré syndrome (GBS) suggests a common auto-immune pathogenesis. The major antigen responsible for inducing EAN is a basic myelin protein, P2, MW $15000 \mathrm{D}$, which is located predominantly in the myelin of the peripheral rather than central nervous system. ${ }^{1-3}$ EAN can be transferred with lymph node cells $^{14}$ or a CD4 $+\mathrm{T}$ cell line. ${ }^{5}$ Cell-mediated immune mechanisms are important in pathogenesis because the development of EAN is inhibited by procedures which deplete $T$ cells ${ }^{6}$ but antibodies to $P 2$ can readily be detected in the blood of rats and rabbits with EAN. ${ }^{34}$ Of other myelin components which might induce an auto-immune response the most studied is galactocerebroside; rabbits immunised with this glycolipid develop a demyelinating neuropathy, lacking the perivascular lymphocyte infiltration of EAN and GBS, probably owing to complement-fixing antibodies directed against

Address for reprint requests: Dr J B Winer, Department of Neurology, St Mary's Hospital, Praed Street, London W2 1NY, UK.

Received 7 August 1987 and in revised form 18 November 1987. Accepted 24 November 1987 galactocerebroside on the Schwann cell surface or in the myelin membrane. ${ }^{7}$ The serum of animals with EAN contains factors which induce demyelination in tissue culture or in vivo when injected into rat sciatic nerve. ${ }^{89}$

Previous investigations of autoimmune responses in GBS have not established the presence of immune responses similar to those in EAN. ${ }^{1011}$ We have taken advantage of a case-controlled prospective study of 100 patients with acute idiopathic neuropathy who were thought on presentation to have GBS to seek evidence of auto-immune responses to nerve antigens. We have also reexamined the disputed question whether blood lymphocyte subpopulations are perturbed ${ }^{1213}$ and investigated the possible involvement of immune complexes and complement.

\section{Methods}

Patients Patients with acute idiopathic neuropathy were recruited in a prospective study in South-East England during 1983 and 1984. Diagnostic criteria at entry to the study fulfilled those promulgated by an ad hoc committee of the NINCDS ${ }^{14}$ for Guillain-Barré syndrome: progressive weakness of two or more limbs due to peripheral neuro- 
pathy, reduced or absent tendon reflexes, and absence of toxic or other recognised cause. Three of these patients subsequently pursued a course more in keeping with a chronic progressive or relapsing neuropathy. Clinical details have been described in a preceding publication. ${ }^{15}$ There were 63 males and 37 females aged between 2 and 79 years. Venous blood samples were collected between 1 and 59 days after the onset of symptoms. Further samples were collected about 3 weeks later. Each patient was matched with a hospital control of the same sex and within 10 years of the same age. Hospital controls were patients admitted to hospital for minor general surgery, (76) cervical spondylotic radiculopathy, (8) or lumbar disc disease. (16)

Lymphocyte subpopulations The total venous blood lymphocyte concentration was deduced from the total white cell count measured with a Coulter counter and the percentage of lymphocytes in a blood film. Blood mononuclear cells were separated on a ficoll-triosil gradient and stored in liquid nitrogen. The lymphocyte subpopulations of coded aliquots were estimated with an Ortho flow cytometer and the Becton-Dickinson monoclonal antibodies, Leu 4 (pan T cell marker), Leu 3 (CD4 + lymphocytes), and Leu 2 (CD8 + lymphocytes). The coefficient of variation in replicate assays was $3 \cdot 9-6 \cdot 3 \%$.

Immunoglobulins, complement and immune complexes Serum was separated within 6 hours of collection and stored at $-70^{\circ} \mathrm{C}$. Immunoglobulins were measured by turbidometry with antisera to IgG, IgA and IgM. The normal ranges (mean, $+2 \mathrm{SD}$ ) of 95 healthy blood donors were for IgG 9.0-18.5 g/l, for IgA 0.8-4.6 g/l and for IgM 0.4-3.0 g/l. Concentrations of complement components $\mathrm{C} 3$ and $\mathrm{C} 4$ were measured in the serum by radial immunodiffusion and expressed as a percentage of normal human pooled serum. Total haemolytic activity was assayed by adding serum to an agarose plate containing a standard quantity of sheep red cells sensitised with rabbit anti-sheep red cell antibody. Circulating soluble immune complexes were sought with a radioiodinated $\mathrm{Clq}$ binding assay. ${ }^{16}$ Samples were frozen and thawed only once.

Complement-fixing antibodies Serum stored at $-20^{\circ} \mathrm{C}$ was tested in a microcomplement fixation assay with three minimum haemolytic doses of guinea-pig complement against homogenates of human and rabbit sciatic nerve, human optic nerve and galactocerebroside as previously described. ${ }^{17}$

Enzyme-linked immunoassay The enzyme-linked immunoabsorbent assay (ELISA) against galactocerebroside was carried out as previously described. ${ }^{17}$ For the ELISA against P2, a "sandwich" technique was used. The wells of microtitre plates were incubated with affinity purified rabbit anti-bovine-P2 antibody, washed, incubated with $100 \mathrm{ng}$ human $\mathrm{P} 2$, and then washed with $0.5 \%$ gelatin to reduce non-specific binding. The wells were incubated with test human sera in serial dilutions from 1:30-1:810 for 2 hours at $4^{\circ} \mathrm{C}$. Binding was identified with Dako antihuman $y$ and $u$ chain serum conjugated with peroxidase and developed with o-phenylene diamine. The intensity of the colour developed was measured at $490 \mathrm{~nm}$ with a Titertek multiscan microelisareader.

Histochemical detection of antibodies to nerve antigens Antibodies to nerve antigens were sought by an indirect immunoperoxidase test with fixed cryostat cut sections of rat sciatic nerve. Sections were fixed with formalin-alcohol for screening for anti-myelin antibodies and acetone for antiaxonal antibodies. Positive results were identified with peroxidase conjugated rabbit antiserum to human IgM, G and A (Dako) diluted 1:20.

Intraneural injections of serum Sera were selected from five severely affected patients in the first week of GBS. Patient serum $(40 \mu \mathrm{l})$ was injected into one and the same amount of control serum into the other sciatic nerve with a $\mathbf{3 0}$ gauge needle and micromanipulator. ${ }^{18}$ Sera were coded before injection and five nerves were injected with each serum. Six days later the rates were perfused with $2 \cdot 5 \%$ glutaraldehyde and the demyelinated fibres in transverse $l \mu$ toluidine blue stained sections were counted at $\times 500$ magnification with the aid of a graticule.

Statistical methods Differences between two proportions were tested for significance by Fisher's exact test or $\chi^{2}$ tests where appropriate. Differences between pairs of means were tested with Student's $t$ test and Dunnett's test was used to compare several means with a single control group.

\section{Results}

Blood lymphocytes and subpopulations Total blood lymphocyte and lymphocyte subset counts were normal in most patients with GBS (fig 1). However, nine of 71 patients and two of 34 hospital controls had lymphocyte counts less than two standard deviations below the mean of the healthy blood donors. Similarlyo $T$ lymphocytes (fig $1 \mathrm{~b}$ ) were reduced more than two standard deviations below the healthy blood donorvalues in 10 patients and only four hospital controls, CD4 + lymphocytes (fig 1c) in 11 patients and four hospital controls and CD8 + lymphocytes (fig 1d) in two patients and one control. None of these proportions is significantly different. The frequency of increased counts of concentrations of lymphocytes and their subsets was similar in the GBS patients and hospital controls. When the lymphocyte counts were analysed related to the interval after onset of neuropathy the only significant feature was that the CD8 + lymphocyte numbers were lower in those GBS patients who were studied in the first week of the disease than in the healthy blood donors (Dunnett's test $\mathrm{p}<0.01$ fig $1 \mathrm{~d}$ ).

The lymphocyte results were compared in the subgroups of patients in which recent cytomegalovirus (CMV) or campylobacter infection had been identified serologically. ${ }^{19}$ Cytomegalovirus infection was associated with a reduction in blood CD4 + lymphocytes while the number of CD8 + cells was not significantly different from that in healthy controls (table 1). In contrast the mean CD8 + lymphocyte count was lower in patients developing GBS following campylobacter infection and in GBS patients without evidence of infection with either campylobacter or CMV than in healthy controls (table 1). The patients who were still so disabled that they were incapable of 

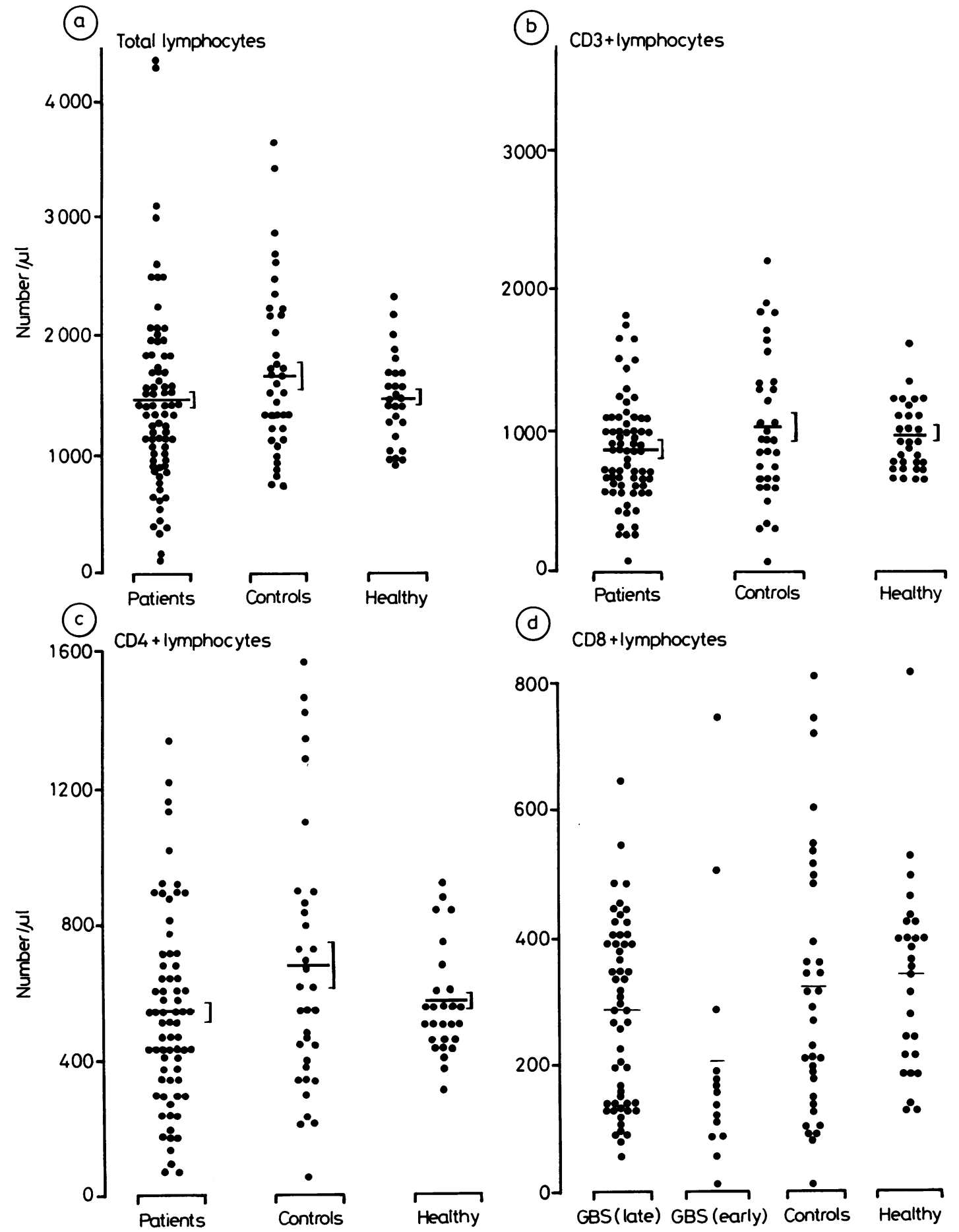

CD8 +lymphocytes

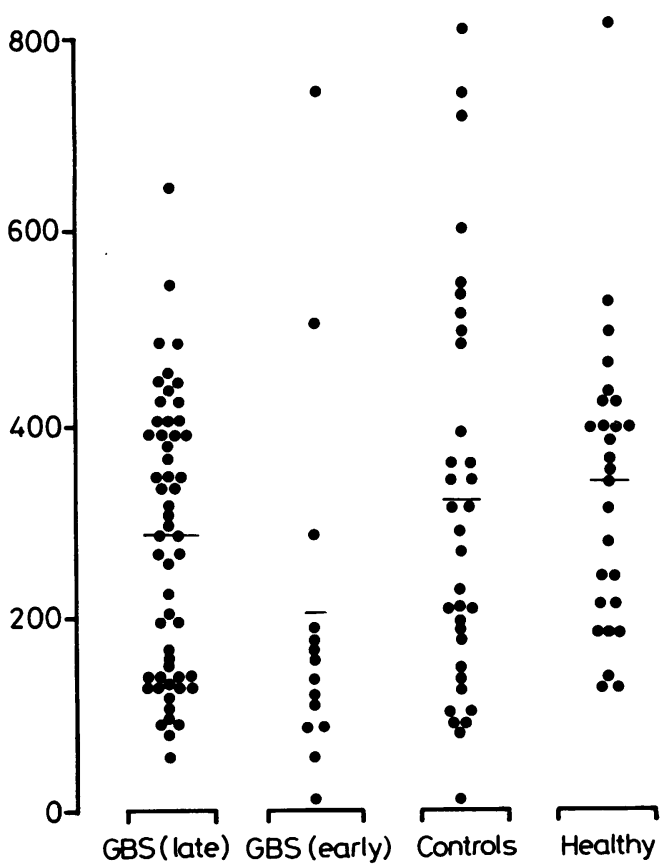

Fig 1 Blood lymphocyte and subset numbers among GBS patients, hospital controls and healthy blood donors. (a) Total lymphocyte counts, (b) CD3 positive cells, (c) CD4 positive cells, (d) CD8 positive cells according to time of sampling (early $<7$ days after onset of neuropathy, late-8 days or greater). 
Table 1 Numbers of lymphocyte subsets in the blood of patients with GBS subdivided according to the serological evidence of recent infection (means $S E$ )

\begin{tabular}{|c|c|c|c|c|}
\hline & \multicolumn{2}{|l|}{ GBS patients } & \multirow[b]{2}{*}{ Remainder } & \multirow[b]{2}{*}{$\begin{array}{l}\text { Healthy blood } \\
\text { donors }\end{array}$} \\
\hline & $\begin{array}{l}\text { Positive campylobacter } \\
\text { serology }\end{array}$ & $\begin{array}{l}\text { Positive CMV } \\
\text { serology }\end{array}$ & & \\
\hline Number of patients & 11 & 8 & 50 & 27 \\
\hline $\begin{array}{l}\text { CD8 }+/ \mu l \\
\text { CD4 }+/ \mu \mathrm{l} \\
\text { CD3 }+/ \mu 1 \\
\text { Total lymphocytes } / \mu l\end{array}$ & $\begin{array}{r}266(51) \\
661(121) \\
898(121) \\
1549(233)\end{array}$ & $\begin{aligned} 310 & (27) \\
362 & (85) \dagger \\
737 & (70) \\
1252 & (160)\end{aligned}$ & $\begin{array}{c}265(23)^{*} \\
561(36) \\
881(55) \\
1399(97)\end{array}$ & $\begin{array}{r}345(29) \\
570(30) \\
983(48) \\
1470(72)\end{array}$ \\
\hline
\end{tabular}

${ }^{*} \mathrm{p}<0 \cdot 1$ Dunnett's test.

$t_{\mathrm{p}}<0.01$ Dunnett's test.

manual work after one year had slightly lower CD8 + lymphocyte counts in the acute stage (mean, SD 213 $138 / \mu \mathrm{l})$ than those who made a good recovery $(290$, $160 / \mu \mathrm{l})(\mathrm{p}=0.05$, Student's $t$ test $)$.

Immunoglobulin and complement and immune complexes Serum IgG concentrations were increased above the normal range in 17/100 GBS patients but also in 15/100 hospital controls and the mean concentrations, SD were not significantly different, being $14.50,6.00 \mathrm{~g} / 1$ in the patients and $14.83,5.83 \mathrm{~g} / 1$ in the controls. Serum IgA concentrations were increased above the normal range in $23 / 100$ patients compared with $13 / 100$ controls $(p=$ $0 \cdot 1)$ and the mean concentration $(3.64,1.54 \mathrm{~g} / \mathrm{l})$ was slightly but not significantly greater than in controls $(3.39,1.75 \mathrm{~g} / \mathrm{l})$. Serum IgM concentrations were increased above normal in 21 patients compared with 11 controls $(\mathrm{p}=0.08)$ and the mean concentration $(2.28,1.23 \mathrm{~g} / \mathrm{l})$ was slightly greater than in controls $(1.88,0.90 \mathrm{~g} / 1)$.

The mean serum C3 (142, SD 35) and C4 (154, SD 41) concentrations of GBS patients and matched hospital controls (132, SD 36 and 141, SD 48) were higher than those of healthy controls (99, SD 27 and 96, SD 25 respectively). No individual GBS patient had low $\mathrm{C} 3$ or $\mathrm{C} 4$ concentrations suggestive of complement consumption. No correlation was discovered between outcome or recent campylobacter or cytomegalovirus infection and the concentrations of $\mathrm{C} 3$ or C4. Concentrations of $\mathrm{C} 3$ tended to fall with increasing time $(r=-0.19 p<0.05)$ from onset of the neuropathy whereas the $\mathrm{C} 4$ concentrations did not alter significantly. Seven of 76 GBS patients and four of 62 hospital controls had diminished serum total haemolytic complement activity which was severely diminished in one of each group. Only three patients had serum Clq binding levels exceeding the mean of the hospital controls by more than two standard deviations suggesting the presence of immune complexes. These three were all among the 11 who had serological evidence of recent $\mathrm{CMV}$ infection.
Autoantibodies to nerve Complement fixing antibodies to nerve antigens were detected in $7-11 \%$ of patients with GBS, significantly more frequently than in controls (table 2). The highest titre at which a positive result was obtained was 1:512. The enzyme linked immunoassay for antibodies to galactocerebroside gave higher results in the serum from GBS patients than control subjects (fig 2). Thirty four per cent of patients compared with $17 \%$ of control sera had ELISA antibody exceeding 0.5 absorbance units $(\mathrm{p}<$ 0.05 ). No association existed between the presence of complement fixing antibodies to nerve antigens or antibodies to galactocerebroside detected by ELISA and outcome at 3 or 12 months, peak disability, duration of neuropathy or serological evidence of infection with campylobacter or cytomegalovirus.

Table 2 Numbers of subjects with increased complement fixing antibody titres to nerve antigens

\begin{tabular}{llc}
\hline & Controls & GBS \\
\hline Human sciatic nerve & 1 & 7 \\
Human optic nerve & 2 & $11^{*}$ \\
Rabbit sciatic nerve & 0 & $7^{*}$ \\
Galactocerebroside & 0 & 0 \\
\hline${ }^{*} \mathrm{p}<0.05$ & &
\end{tabular}

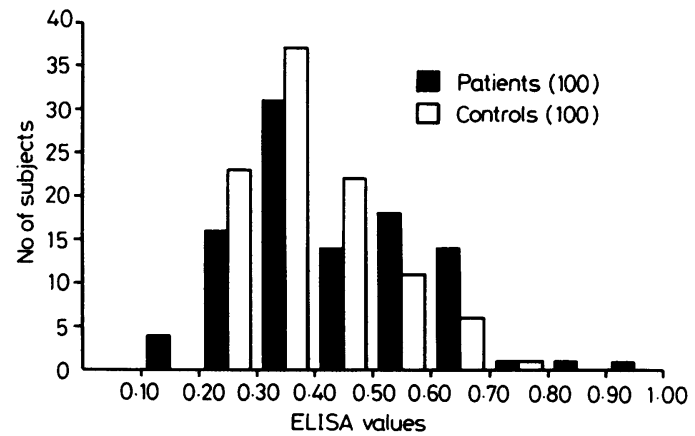

Fig 2 Antibodies to galactocerebroside detected by ELISA in $G B S$ patients and controls. 
Sera from 10 patients with severe GBS within the first 5 days of the illness and from 10 with severe GBS in the second month of the illness were tested for antibodies to P2 with the ELISA but none gave readings higher than the sera from the matched controls. With the indirect immunoperoxidase test for antibodies to nerve antigens, more sera from GBS patients than controls reacted with myelin $(7 / 58$ compared with $1 / 58, \mathrm{p}=0.06)$ and axons $(9 / 58$ compared with $2 / 58, \mathrm{p}=0.05$ ) at titres of $>1: 20$.

Intraneural injection of serum into rat sciatic nerves There was no qualitative or quantitative difference in the morphological appearances of the nerves injected with GBS as compared with control serum. In the nerves injected with GBS serum between 0 and 129 (median 15) nerve fibres were demyelinated. In those injected with control serum between 0 and 130 (median 24).

\section{Discussion}

This study confirms our previous finding of reduced numbers of CD8 + lymphocytes in the peripheral blood of some patients with GBS ${ }^{12}$ and extends the previous report by showing that the reduction was more marked during the first week of the disease and depended on the nature of the preceding infection. The CD8 + lymphocytes were reduced in the blood of those patients who had serological evidence of recent campylobacter infection. By contrast the CD8 + lymphocytes were slightly increased and the CD4 + cells reduced in the blood of patients with recent CMV infection, which are the usual changes observed in acute CMV infection not complicated by GBS. ${ }^{20}$ The conclusion that the concentrations of lymphocyte subset populations in the blood depend on the preceding infection offers an explanation of the discrepant observations concerning lymphocyte subpopulations in smaller series of GBS patients. ${ }^{121321}$ In those patients who have decreased blood CD8 + cells, the decrease might be caused by increased lysis possibly by cytotoxic antibodies against antigens shared by Schwann cells or myelin and CD8 + cells, or sequestration of CD8 + cells in the inflammatory lesions in nerves or roots or in lymphoid organs, or modulation of CD8 antigen expression on the cell surface.

The functional significance of the reduction in blood CD8 + cells is uncertain; it might contribute to a reduction in the normal level of $T$ cell suppression and so release auto-immune mechanisms. Clinical observation makes this unlikely since GBS, and progressive multiple sclerosis in which the same phenomenon is observed, are not frequently accompanied by the wide range of auto-immune phenomena which might be expected from this hypothesis. A specific loss of $T$ suppressor cells regulating only anti-myelin responses would be unlikely to alter total CD8 + numbers significantly. The data suggested a relationship between $\mathrm{CD} 8+$ cell numbers and outcome in that the CD8 + cell numbers in the acute stage were lower in patients who were left disabled than in those who went on to recover fully.

Our finding of normal or increased serum C3 and C4 concentrations agrees with the one previous report. ${ }^{22}$ We were surprised not to identify immune complexes by the Clq binding assay in the serum of patients with GBS since immune complexes have been identified by a test for inhibition of $\mathrm{K}$ cell killing, ${ }^{23}$ by Raji cell assay ${ }^{24}$ and by Clq binding. ${ }^{25}$ The three patients in whose serum immune complexes were identified had serological evidence of recent CMV infection.

We only identified complement fixing antibodies to nerve antigens in a small proportion of sera from GBS patients. These results are similar to those which we reported in a retrospective series of 17 patients with GBS $^{17}$ and contrast with our own finding of the high incidence of complement-fixing antibodies to myelin present in high titre in the serum of patients with $\operatorname{IgM}$ kappa monoclonal gammopathy of undetermined significance and demyelinating neuropathy. ${ }^{26}$ Ryberg and colleagues ${ }^{27}$ reported a somewhat higher proportion of GBS sera reacting with nerve homogenate in a complement fixation test $7 / 18$ in the first 3 weeks, $4 / 11$ in weeks $4-8$ and $0 / 8$ after 8 weeks. While this study was in progress Koski and colleagues ${ }^{28} 29$ reported that complement-fixing antibodies to myelin can be detected in low titre in the serum of patients with GBS in the first week of the disease but that the titre diminishes rapidly during the next 3 weeks. Their technique detects the binding of $\mathrm{Clq}$ and is reported to overcome the problem of anti-complementary activity which prevents the reliable detection of low titres of antibody with our conventional complement fixation test and might account for the difference between our results.

As in our previous smaller study ${ }^{17}$ complement fixing antibodies to galactocerebroside were absent but the GBS sera reacted more strongly with galactocerebroside than hospital control sera in the ELISA test. These results do not favour a role for antigalactocerebroside antibody in GBS since the serum of rabbits with demyelinating neuropathy after immunisation with galactocerebroside has high complement fixing antibody titres to that antigen. ${ }^{7}$

In our previous study ${ }^{17}$ we could only identify antibodies to bovine $\mathbf{P} 2$ in one of 17 sera from patients with GBS by an assay in which radioactively labelled $\mathrm{P} 2$ is precipitated by any antibody present in the test serum, a test which is positive during actively induced 
EAN in Lewis rats. Zweiman et al ${ }^{30}$ were only able to identify antibodies to P2 by an ELISA technique in one of 19 GBS patients. In the present study we modified the ELISA by fixing the P2 to the test using polyclonal anti $\mathbf{P} 2$ antiserum to present $\mathbf{P} 2$ to the test sera in the hope of presenting a greater variety of $\mathrm{P} 2$ epitopes than are accessible with $\mathrm{P} 2$ bound directly to ELISA plates. We still failed to identify any positive sera despite selecting sera from severely affected patients in acute and convalescent stages. In a further attempt to detect an immune response we repeated the plaque forming cell assay of Luijten and colleagues. ${ }^{31}$ Those authors cultured lymphocytes from the blood of patients with GBS in the presence of human P2 and showed that some of these lymphocytes in the presence of complement would lyse sheep red cells coated with P2 so as to form a "plaque". In tests on five GBS patients and five controls we found that as many plaques were formed by the control as the patient lymphocytes and that the same result could be obtained with a control antigen, calf thymus histone, as with $\mathbf{P} 2$.

The detection of antibodies to nerve antigens by the indirect immunoperoxidase test is made more difficult because myelin possesses Fc receptors which cause false positive reactions. Using the conservative criterion of a positive reaction at a $1 / 40$ serum dilution we found that sera from a small number of GBS patients contained antibodies against myelin or axons. It was notable that all of the six sera which had serological evidence of recent CMV infection and were tested for antiaxonal antibodies gave positive results. The responsible antigen has not been identified.

Our failure to identify a significant demyelinating effect following injection of serum from patient with acute severe GBS into rat sciatic nerve has to be considered in the context of a conflicting literature. ${ }^{32-34}$ Although the injection of large amounts of fresh GBS serum into rat sciatic nerve does cause more demyelination that control serum, this effect has to be interpreted when superimposed on the artefact of injecting large amounts of protein rich fluid into a small protein-poor endoneurial space. The effect is lost if the serum is frozen and then thawed ${ }^{33}$ which would explain why we failed to identify any significant effect, and which militates against the effect being due to a conventional antibody.

Although our investigation has failed to identify a specific auto-immune response we consider that the antibodies which we have demonstrated in a small proportion of patients may be the footprints of a more important auto-immune reaction. We are interested in the recent report that Geczy et al ${ }^{35}$ have identified cell-mediated immunity to P2 in GBS with a sensitive in vitro test. P2 has a structure which is highly conformationally dependent so that negative results may have been caused by loss of the appropriate epitope, which would be more likely to be important in detecting antibody than cell-mediated immunity since antibody recognition depends on tertiary and $T$ cell recognition mainly on secondary structure. ${ }^{36}$ It is also possible that other antigens, including P0 which we have recently shown to be capable of inducing $\mathrm{EAN},{ }^{37}$ are important and the responsible antigen(s) vary from patient to patient.

JBW was a Williams research fellow of the University of London. We thank the Multiple Sclerosis Society of Great Britain and Medical Research Council for financial support and Mrs Sheila Button for typing the manuscript.

\section{References}

1 Abramski O, Teitelbaum D, Arnon R. Experimental allergic neuritis induced by a basic neuritogenic protein (PIL) of bovine peripheral nerve origin. Eur J Immunol 1977:7:213-7.

2 Kadlubowski M, Hughes RAC, Gregson NA. Experimental allergic neuritis in the Lewis rat: characterization of the activity of peripheral myelin and its major basic protein, P2. Brain Res 1980;184:439-54.

3 Kadlubowski M, Hughes RAC, Gregson NA. Spontaneous and experimental neuritis and the distribution of the myelin protein P2 in the nervous system. $J$ Neurochem 1984;42:123-9.

4 Hughes RAC, Kadlubowski M, Gray IA, Leibowitz S. Immune o responses in experimental allergic neuritis. J Neurol Neurosurg Psychiatry 1981;44:565-9.

5 Linington C, Izumo S, Suzuki M, Uyemura K, Meyerman R, Wekerle $\mathrm{H}$. A permanent rat $\mathrm{T}$ cell line that mediates EAN in the Lewis rat in vivo. J Immunol 1984;133:1946-50.

6 Brosnan JV, Craggs RI, King RHM, Thomas PK. Reduced sus-: ceptibility of $\mathrm{T}$ cell deficient rats to induction of experimental allergic neuritis. $J$ Neuroimmunol 1987;14:267-83.

7 Saida T, Saida K, Silberberg DH, Brown MJ. Experimental allergic neuritis induced by galactocebroside. Ann Neurol 1981;9 (Suppl):87-101

8 Saida T, Saida K, Silberger DH, Brown MJ. Transfer of demyelination with experimental allergic neuritis serum by intraneural injection. Nature 1978;272:639-41.

9 Hahn AF, Gilbert JJ, Feasby TE. Passive transfer of demyelination by experimental allergic neuritis serum. Acta Neuropathol (Berlin) 1980;49:169-78.

10 Arnason BGW. Acute inflammatory polyneuropathies. In: Dyck PJ, Thomas PK, Lampert EH, Bunge R, eds. Peripheral Neuropathy, Philadelphia, W Saunders Vol II 1984:2050-100.

11 Hughes RAC, Winer JB. Guillain-Barré syndrome. In: Matthews WB, Glaser GH, eds. Recent Advances in Clinical Neurology4, Edinburgh. Churchill Livingstone 1984:19-49.

12 Hughes RAC, Aslan S, Gray IA. Lymphocyte subpopulations and suppressor cell activity in acute polyradiculoneuritis. Clin Exp Immunol 1983;51:448-54.

13 Lisak RP, Zweiman B, Guerro F, Moskovitz AR. Circulating T cell subsets in Guillain-Barré syndrome. Ann Neurol 1983; 14:115.

14 Asbury AK. Diagnostic considerations in Guillain-Barré syndrome. Ann Neurol 1981;9 (Suppl): 1-5.

15 Winer JB, Hughes RAC, Osmond C. A prospective study of acute idiopathic neuropathy. 1) Clinical features and their prognostic value. J Neurology Neurosurgery Psychiatry. 1988;51:605-12.

16 Zubler RH, Lange PH, Miescher PA. Detection of immune complexes in unheated sera by a modified 125 -Clq binding test. $J$ Immunol 1976;116:232-5. 
17 Hughes RAC, Gray IA, Gregson NA, Kadlubowski M, Kennedy $\mathbf{M}$, Leibowitz $\mathbf{S}$, Thompson $\mathbf{H}$. Immune responses to myelin antigens in Guillain-Barré syndrome. $J$ Neuroimmunol 1984;6(5):303-12.

18 Hughes RAC, Powell J. Endoneurial injection of antisera to myelin antigens. Muscle Nerve 1985;8;516-22.

19 Winer JB, Hughes RAC, Anderson MJ, Jones DM, Kangro H, Watkins RPF. A prospective study of acute idiopathic neuropathy. 2) Antecedent events. J Neurology Neurosurgery Psychiatry 1988;51:613-8.

20 Carney WP, Rubin RH, Hoffman RA, Hansen WP, Healey K, Hirsch MS. T cell subset (H:S) ratio in acute human CMV. J Immunol 1981;126:2114-9.

21 Hauser SL, Ropper AH, Perle VP, Reinherz GL, Schlossman SF, Weiner HL. T cell subsets in chronic autoimmune diseases. Neurology 1982;32:1320-1.

22 Tonnessen TI, Nyland H, Aarli JA. Complement factors and acute phase reactants in the Guillain-Barré syndrome. Eur Neurol 1982;21:125-8.

23 Hughes RAC. Acute inflammatory polyneuropathy. In: Rose FC, ed. Clinical Neuroimmunology. Oxford, Blackwell, 1979: 170-84.

24 Tachowski T, Lisak RP, Koprowski H. Circulating immune complexes in multiple sclerosis and other neurological disorders. Lancet 1976;ii:997-9.

25 Goust JM, Chenais F, Carnes JE, Hames CG, Fudenberg HH, Hogan EL. Abnormal T cell subpopulations and circulating immune complexes in the Guillain-Barré syndrome and multiple sclerosis. Neurology 1978;28:421-8.

26 Leibowitz S, Hughes RAC. Experimental allergic neuritis, human poly-radicoloneuritis and related disorders. In: Immunology of the nervous system. London: Edward Arnold, 1983:101-30.

27 Ryberg B. Extra and intrathecal production of antinerve and antibrain antibodies in Guillain-Barré syndrome: Evaluation by an antibody index. Neurology 1984;34:1378-81.
28 Koski CL, Humphrey R, Shin ML. Antiperipheral myelin antibody in patients with demyelinating neuropathy: Quantitative and kinetic determination of serum antibody by complement 1 fixation. Proc Natl Acad Sci (USA) 1985;82:905-9.

29 Koski CL, Gratz E, Sutherland J, Mayer RF. Clinical correlation with anti-peripheral nerve myelin antibodies in Guillain-Barré syndrome. Ann Neurol 1986;19:573-7.

30 Zweiman B, Rostami A, Lisak RP, Moskovitz AR, Pleasure DE. Immune reactions to $\mathbf{P} 2$ protein in human inflammatory demyelinating neuropathies. Neurology 1983;33:234-7.

31 Luijten JAFM, De Jong WAC, Demel RA, Heijnen CH, Ballieux RE. Peripheral nerve P2 basic protein and the Guillain Barré syndrome: In vitro demonstration of P2 specific antibody secreting cells. J Neurol Sci 1984;66:209-16.

32 Sumner AJ, Saida K, Saida T, Silberger D, Asbury AK. Acute conduction block associated with esperimental anti serummediated demyelination of peripheral nerve. Ann Neurol 1982:11:469-77.

33 Harrison BM, Hansen LA, Pollard JD, McLeod JG. Demyelination induced by serum from patients with Guillain Barré syndrome. Ann Neurol 1984;15:163-70.

34 Brown MJ, Rosen JL, Lisak RP. Demyelination in vivo by Guillain-Barré syndrome and other human serum. Muscle Nerve 1987;10:263-71.

35 Geczy C, Raper R, Roberts IM, Meyer P, Bernard CCA. Macrophage procoagulant activity as a measure of cell mediated immunity to $\mathbf{P} 2$ protein of peripheral nerves in Guillain-Barré syndrome. J Neuroimmunol 1985;9:179-91.

36 Margalit H, Spough JL, Cornette JL, Crease KB, Delisi C, Bersofsky J. Prediction of immunodominant helper T cell antigenic sites from the primary sequence. J Immunol 1987; 138:2213-29.

37 Milner P, Lovelidge CA, Taylor WA, Hughes RAC. Po myelin protein produces experimental allergic neuritis in Lewis rats. J Neurol Sci 1987;79:275-85. 